\title{
RESEARCH PAPER \\ The rise and fall of Chanco cheese in Chile (1860-1930)
}

\author{
Pablo Lacoste ${ }^{1}$, Amalia Castro², Diego Jiménez ${ }^{1}$, Natalia Sotoํ, Bibiana \\ Rendón $^{3}$, and Félix Briones ${ }^{4}$ \\ 'Instituto de Estudios Avanzados, Universidad de Santiago de Chile. Román Díaz 89. Santiago, Chile. \\ ${ }^{2}$ Escuela de Historia, Facultad de Comunicaciones y Humanidades, Universidad Finis Terrae, Av. Pedro de \\ Valdivia 1509, Santiago, Chile. \\ ${ }^{3}$ Facultad de Filosofía y Humanidades, Universidad de Chile. Ave. Capitán Ignacio Carrera Pinto 1025, \\ Ñuñoa, Santiago, Chile. \\ ${ }^{4}$ Departamento de Ciencias Sociales, Universidad del Bío-Bío sede La Castilla. Ave. Andrés Bello s/n, \\ Chillán, Chile.
}

\begin{abstract}
P. Lacoste, A. Castro, N. Soto, B. Rendón, F. Briones, and D. Jiménez. 2015. The rise and fall of Chanco cheese in Chile (1860-1930). Cien. Inv. Agr. 42(1): 85-96. This paper studies the historical evolution of Chanco cheese during two very different time periods: $1860-1900$ and 1900-1930. The former was characterized by a high presence of the aforementioned cheese in Chilean society, and the latter period encompassed a time of identity contamination. Unlike Pisco, which has been delimited and protected as an Appellation of Origin (AO), Chanco cheese has been a victim of dilution of its own identity and cultural value. We hypothesize that the dilution and devaluing of Chanco cheese was a result of the incoherent actions of the State, producers and merchants with respect to its assessment, protection and delimitation of its identity.
\end{abstract}

Key words: Agro foods, Appellations of Origin, Chanco cheese, Chile, identity contamination.

\section{Introduction}

Traditionally, Chanco cheese has been the most important cheese made in Chile since the 18th century (Molina, 1987; Lacoste et al., 2014, Pereira, 1977). At the end of the colonial period (19th century), Chanco cheese became widely known in Chile because of its identity as a cheese produced in a specific territory, Maule Sur, located

Received July 8, 2014. Accepted March 16, 2015. Corresponding author: pablo.lacoste@usach.cl between the Maule and Itata rivers in the presentday Cauquenes province. This cheese was made from available raw materials, sheep (majority) and cow milk, and by a unique production method that produced a boiled, mature cheese.

In the traditional period of the Chilean economy, from colonial times to halfway through the 19th century, Chanco cheese stood out as a product with exceptional quality (Lacoste et al., 2014). Along with Pisco, a wine brandy made in Norte Chico, Chanco cheese was the main agro food of colonial Chile and was recognized as a geographi- 
cally identifiable product (Coello, 2008) because of its intrinsic quality.

The rising recognition that Chanco cheese had developed since the 18th century until its consolidation in the 19th century suggested that this product would be soon be recognized and protected by an Appellation of Origin (AO), if it had followed a similar path as Chilean Pisco, Spanish Rioja wine, Portuguese Port and some of the more than 700 internationally recognized AOs of France (Coello, 2008). However, Chanco cheese has not been registered as an $\mathrm{AO}$ nor as a Geographic Indication (GI); what were the factors hindering its development as an AO? What were the social, political and cultural forces that impeded its definitive consolidation? To clarify these questions, the present article examines the history of Chanco cheese since 1860 and analyzes what has happened in the years since.

\section{Materials and methods}

We used the critic-heuristic approach, the base method of historical analysis, in three phases: a historical description of the entire period, a separated analysis of each period (1860-1900 and 1900-1930), and a comparative survey between the two time periods. We used press notes and newspaper ads from the aforementioned periods as primary sources. For secondary sources, we utilized historical research and agronomical inquiries from prominent authors on the topics discussed in this paper.

\section{Results and discussion}

For cheeses, the European concept of AO evokes a legal, social, and economic protection system of an agro food developed in a very specific region by means of a "collective-specific knowledge". It acknowledges a product for its quality, which is strongly associated with its territorial origin and handcrafted cheese-making (Perrier-Cornet and Sylvander, 2000). The AO for cheeses has been strongly linked to the development of rural communities through collectively coordinated strategies focused on stimulating cooperation and protecting producers' property rights (Delfosse, 1997; Perrier-Cornet and Sylvander, 2000).

To make the AO system possible, France (and almost all of Europe) endured a very complex period spanning from the last third of the 19th century to the last years of the first third of the 20th century, in which they developed a culture against the fraud and falsification of products' origin. An AO requires cooperation between producers and the support of technicians (Delfosse, 1997). However, an essential factor in establishing an AO is the consistency of the State's action to legally protect geographically identified typical products, involving collaboration of parliamentarians, producers, lobbyists, technicians and executive officers to protect the identity, origin and quality of these products to preserve their own national identity (Defolsse, 1997; Perrier-Cornet and Sylvander, 2000).

In the next sections, we will evaluate whether the abovementioned processes had a significant influence in the case of Chanco cheese in Chile during two historical time periods (1860-1900 and 1900-1930).

\section{Chanco cheese and its adaptation to the new socioeconomic context (1860-1900)}

A substantial change took place in the social and economic life in Chile and the world during the second half of the 19th century. A sudden expansion of transport and communications media took place within the framework of the Second Industrial Revolution. There was unprecedented lifestyle transformation that was echoed in the food consumption guidelines. At the same time, a noticeable advancement in education took place across the country. The literate population started increasing gradually, reaching 17\% in 1865 and 
$50 \%$ of total population in 1920 (Dussaillant, 1993). The social advances in education and literacy created the perfect conditions for the expansion of the press.

The golden age of written press took place between 1870 and 1920 in Europe and America. Editors gained easier access to national and international news thanks to the new communications systems (i.e., telegraph, mail, telephone). By publishing news, the newspapers attracted the attention of the public. At the same time, merchants found a proper place to promote their products in those pages. Because of the transportation revolution, the supply of goods increased exponentially, opening the way for commercial competition at national and international scales. The economic agents looked to the press to catch clients' attention, and the press became a means to spread news, as well as advertisements.

The rise of the press in Chile occurred in the capital and in the regions' cities and towns. Dozens of daily and weekly printed copies were sent all over Chile, spreading news of various political, social, economic and cultural issues. El Ferrocarril and El Diario Ilustrado were the main newspapers in Santiago, and in Valparaíso, the main newspaper was El Mercurio de Valparaíso (founded in 1827), which later had to compete with La Unión and other newspapers. The press also flourished in the provincial capitals: El Progreso de Coquimbo and El Coquimbo in Coquimbo, El Tamaya in Ovalle, El Comercio in San Felipe, La Mañana in Talca, La Prensa in Curicó, and La Discusión in Chillán, among others.

Along with the expansion of written press, new spaces opened to promote the mass consumption of products, particularly food. The best place for businesses to promote their offers and attract buyers was in newspapers and periodicals. Both retailers and wholesalers invested large amounts of money to purchase classified advertisements and make their products known, sometimes giving information on quality and price.

For example, advertisements were published in the 1870s and 1880s in El Comercio of San Felipe (March 10, 1877; October 9, 1889) and $E l$ Tamaya of Ovalle (March 15, 1876). In the port of Valparaíso, El Mercurio also contained these types of advertisements (December 2, 1870). Between Coquimbo and La Serena, these commercial ads were frequently found in the pages of El Progreso de Coquimbo and El Coquimbo (December 3, 1895; November 7, 1895; October 3, 1885; January 30) (Figures 1 and 2).
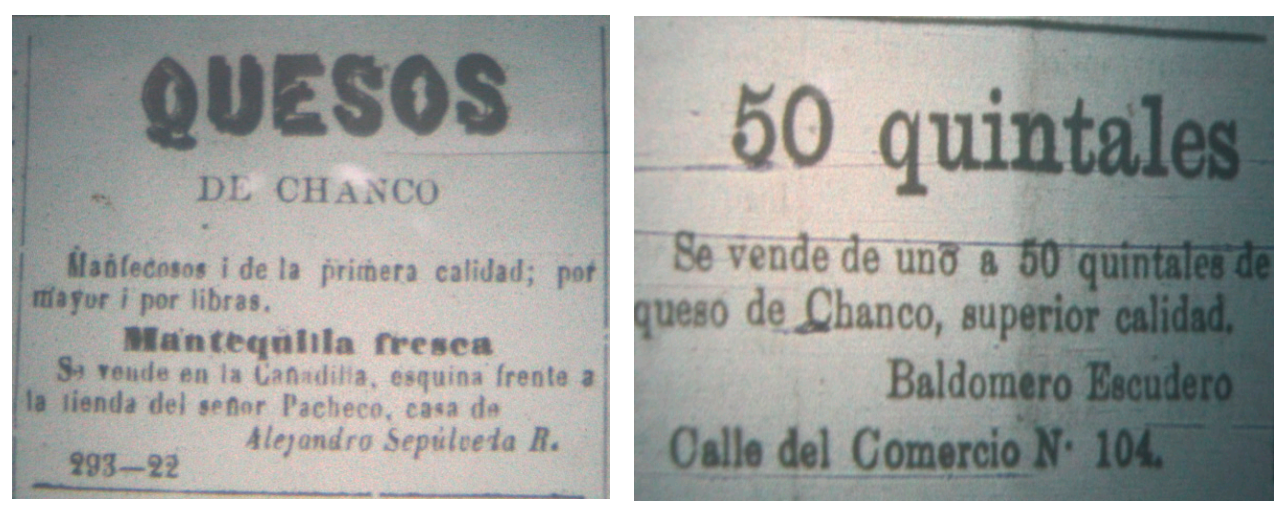

Figure 1. Chanco cheese advertisements. From left to right: El Comercio (San Felipe), March 10, 1877, and El Comercio (San Felipe), August 9, 1889. 

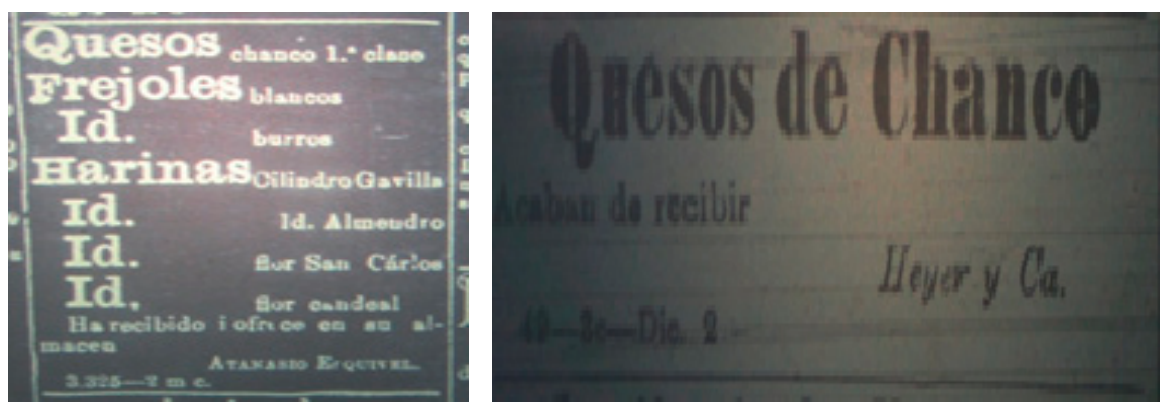

Figure 2. Advertisements for Chanco cheese in Coquimbo and Valparaíso. El Coquimbo, August 25, 1900 (left). El Mercurio de Valparaíso, December 2, 1870 (right).

These illustrations show the differences and similarities between various commercial advertisements that promoted Chanco cheese. In some messages the "Chanco Cheese" legend was stressed with a larger type size. Other examples emphasized the concept of "cheese" or the amount to catch the attention of retail merchants and resellers. Two themes were common to all of the advertisements: Chanco cheese was a product that was worth promoting through the press, and the consumer knew what it was about and valued it as a product. For general stores, Chanco cheese was an emblematic product capable of attracting buyers of other goods. Chanco cheese was an anchor product in the Chilean commercial system in the last third of the 19th century.

Commercial advertisements published in the Chilean newspapers of the capitals, ports, villages and cities contributed to the consolidation of Chanco cheese's presence in markets over the last four months of the 19th century. The written press, the mass media outlet of that epoch, was the most powerful way to promote the mass consumption of typical agro foods in the population. Retailers also contributed to the consolidation of Chanco cheese's image as the country's main food product with geographical identity by financing the publication of those advertisements.

\section{Chanco cheese among reference prices}

The presence of Chanco cheese in the press was perceived not only in advertisements but also in the news, particularly by those devoted to following its prices. The large national newspapers had an ads section focused on reporting price fluctuations in the Chilean agro food market. This section was highly valued by economic agents who needed information to adjust their retail and wholesale transactions. Chanco cheese was found among the selected products that made up a typical Chilean food basket in the 19th century.

In the 1860s, El Ferrocarril recurrently gave information about Chanco cheese's price in the Santiago market. A hundredweight of Chanco cheese was quoted between $\$ 10$ and $\$ 12$ in autumn of 1864 and rose to $\$ 15$ and $\$ 16$ in the winter of that same year (El Ferrocarril, April 12; May 4 and 18; June 6; and August 31, 1864). In the summer of 1869 , it dropped again and was quoted at $\$ 12$ per hundredweight (El Ferrocarril, Santiago, January 20, 1869). In autumn, the price of Chanco cheese rose to $\$ 14$ per hundredweight (El Ferrocarril, Santiago, April 14, 1869) and kept rising up to $\$ 20$, while Valdivia cheese was quoted at \$14 (BSNA, 1870a). In the following decade, the prices increased slightly and reached \$16 to \$17 per hundredweight (El Ferrocarril, Santiago, March 18, 1873, and April 18, 1873).

From 1860 to 1870, the price of Chanco cheese remained relatively stable at around $\$ 15$ per hundredweight, with a minimum of $\$ 12$ and a maximum of $\$ 17$. Thus, Chanco cheese retained its price leadership over other types of cheeses. According to the 19th century press, the price 
of first grade cheese fluctuated between $\$ 11$ and $\$ 12$, while the price of second grade cheese varied between $\$ 9$ and $\$ 9.5$ (El Ferrocarril, Santiago, March 2, 1873). By the mid-1870s, Chanco cheese was valuated at approximately $30 \%$ higher than other cheeses in Chile.

\section{The decline of Chanco cheese in the written press (1900-1930)}

Chanco cheese had a noticeable presence in the media at the beginning of the 19th century until its swan song, which took place in the last quarter of the 19th century. The level reached in that period was not solid enough to create the minimum required framework, but it was rather the ceiling of an ascending cycle prior to the declination stage. The image of Chanco cheese started losing its validity in the markets around the beginning of the 20th century. It was not capable of retaining its position as the most preferred cheese by Chileans; hence, the first third of the 20th century was the period of Chanco cheese's decadence.

The decline of Chanco cheese was clearly visible in the press' advertisements and reports. Chanco cheese disappeared from the list of reference products in the reports of market prices around the beginning of the 20th century, with only a few generic references. For example, the prices reports published between 1908 and 1910 in the pages of El Ferrocarril referred to the oscillations in cheese prices in the food market "according to grade and quantity," without any distinctions between Chanco cheese and other cheeses ( $E l$ Ferrocarril, August 21, 1908; January 22, 1910).

A similar trend was observed in the classified advertisement section, which was published at stores' requests. After 1900, advertisements related to Chanco cheese decreased abruptly. For instance, the press in Norte Chico, which had published many Chanco cheese advertisements in the last decade of the 19th century, included only five ads in the subsequent 30 years: three in El Coquimbo (August 23, 1901; May 1 and June 1, 1905), one in El Progreso de Coquimbo (May 25, 1929), and one in Los Domingos del Progreso (June 16, 1929).

The reduced presence of Chanco cheese in the press since the 19th century was the result of the new marketing strategies adopted by stores. The firm of Andrés Kerr and Co. bought spaces in El Coqui$m b o$ to publish their ads in monthly or bi-weekly intervals between 1896 and 1906. Kerr and Co.'s advertisements were characterized by their size and visibility, and their ads often included a list of the country's products, among which Chanco cheese stood out. For example, Chanco cheese was among four main products in an advertisement published on September 3, 1896, and it was the only one that included data about the cheese's geographic origin. This type of publicity remained, with minor adjustments, in the pages of $E l$ Coquimbo for certain time. However, this strategy gradually started to change. Chanco cheese gradually lost importance after 1897, and imported products slowly began to take its place. The last mention of Chanco cheese appeared on August 23, 1901 (Figure 3). 

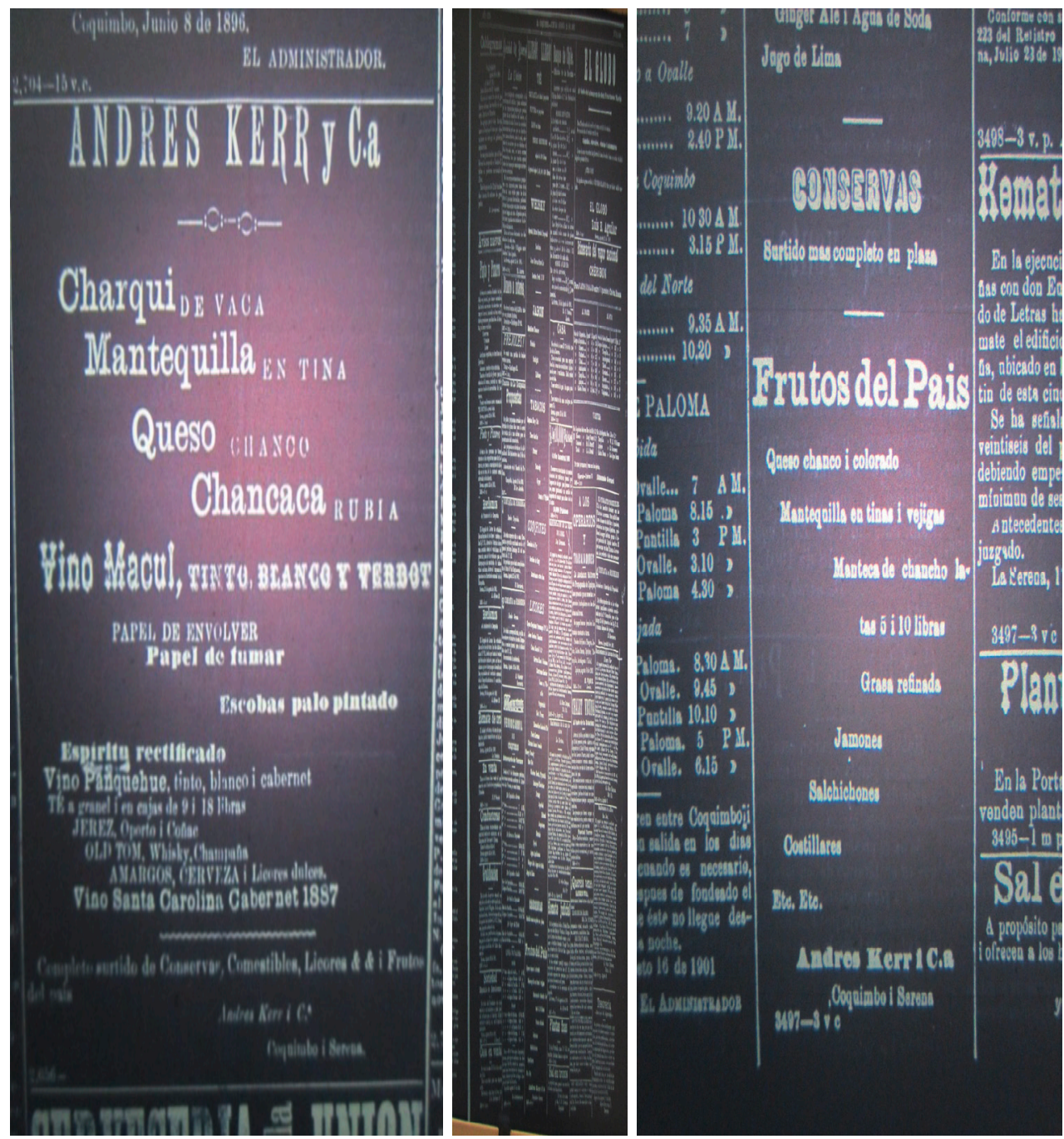

Figure 3. Chanco cheese in Andres Kerr and Co. advertisements. From left to right: El Coquimbo, September 3, 1896, and El Coquimbo, August 23, 1901 (in the middle: complete column; on the right: detail of the bottom part).

The penetration of European products in Chile

The penetration of European products had begun by mid-19th century. The adhesion of Chilean politicians and economists to the free exchange paradigm stimulated cheese importation from Holland, France, England and other countries and resulted in the invasion of the national market with their products. They struggled to displace Chanco cheese from the privileged position as the preferred cheese of the elite. The State aligned itself with this free exchange ideology, and it began to promote customs and commercial policies that reinforced the import of foreign food products, disregarding any impact on the national production and consumption of agro foods. In contrast to the major powers, which took zealous care of their productive sector through commercial policies, Chilean rulers left the national industry to its own fate.

During the second half of the 19th century, the naive open policy of the Chilean State coincided 
with an expansion of the Great Powers within the framework of the second industrial revolution. Technological advances led to a strong increase in goods production and stimulated the search for markets to sell their respective surpluses. The European countries responded to the demand of the largest companies with an aggressive commercial policy that involved all of their political, economic, social, and cultural resources. Chilean products, which were just coming out of the colonial period and trying to adapt to this new international market, had to compete with the main commercial powers $v i s$-á-vis, in the framework of an asymmetric competition (Dussaillant, 1993).

The massive unloading of imported products in Chilean ports coincided with the development of sophisticated marketing strategies with which national producers were not yet acquainted. While national foods were limited to preparing products and transporting them to markets, the foreign competitors, supported by their respective States, had a complex network of commercial links that supported their infiltration of markets through more sophisticated marketing resources that exploited desires and values as symbols of status and prestige (Cavieres, 2008; Dussaillant, 1993).

The big stores held constant campaigns to promote these products through the press all over the country. The Gutiérrez, Gomez y Orrego firm published advertisements highlighting cheese from Switzerland and Holland (El Mercurio de Valparaíso, July 16, 1870), and the Brace, Laidlaw y Co. firm promoted cheese and ham made in England (October 27, 1870) (Figure 4).

The presence of imported products became the norm in Valparaíso's active port. Foreign merchandise was bought and sold, and it was promoted through the media available to the goods market. These products were also auctioned when unforeseen problems prevented its normal marketing and sales. For example, an advertisement for an auction published on July 19, 1870, offered cheese from Holland among other products that had been damaged by sea water (Figure 4).
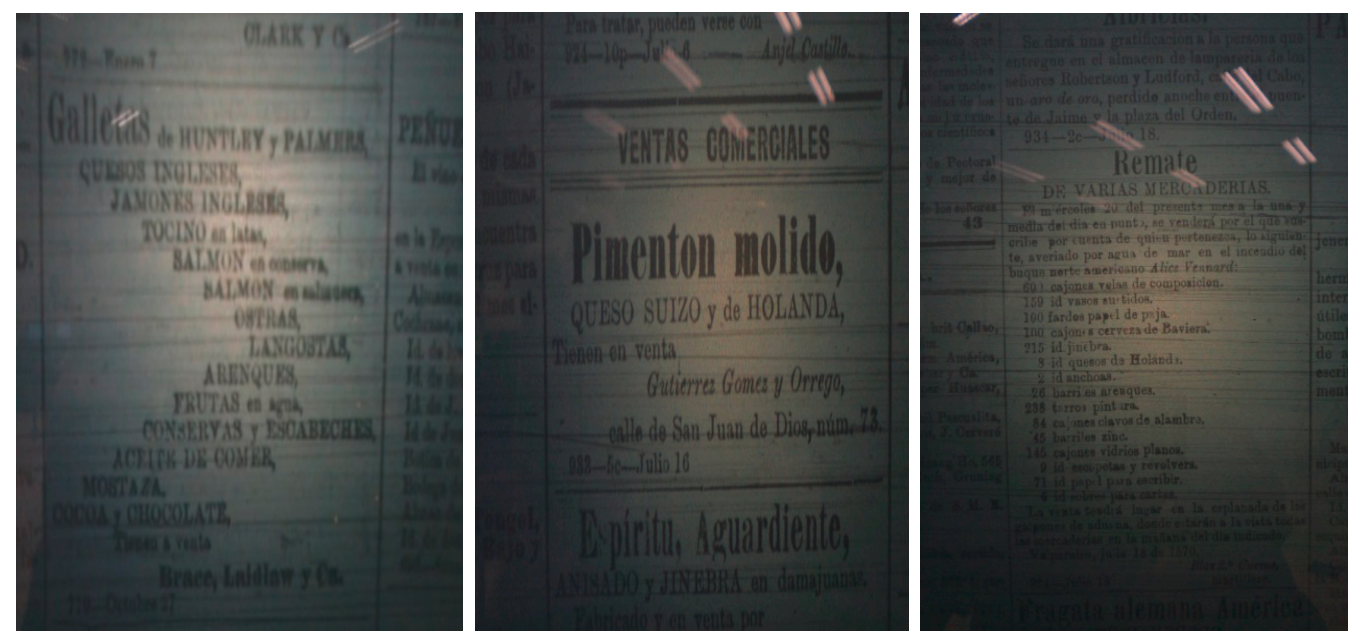

Figure 4. Chilean cheese stocks labeled as foreign cheeses. From left to right: El Mercurio de Valparaíso, October 27, 1870; El Mercurio de Valparaíso, July 16, 1870; and El Mercurio de Valparaíso July 19, 1870. 
The period from 1870 to 1920 tested the strength of the identity and culture of Chilean commercial markets. With their advanced publicity campaigns, the massive penetration of foreign products challenged the traditional adhesion of Chileans towards their own products, particularly Chanco cheese. In France, people valued and consumed the wine and cheese from the country's inner regions because of joint support from the elite and the producers for their national products, a phenomenon common to other European countries as well.

The Chilean elites took the exact opposite attitude of the Europeans. In Europe, the middle and high level consumers consolidated and strengthened the culture of valuing and consuming products of national origin, such as Brie and Roquefort cheese in France, Cheddar cheese in England and Scotland, and cheese from Neufchatel in France, among others. They reinforced their national identity and pride. The Chilean ruling class responded to this phenomenon by shifting away from those proposals, focusing on improving importation of foreign products instead of strengthening the identity and value of Chilean agro foods. Food became a differentiating factor. Imported products, which were more expensive, indicated a greater capacity for consumption and distinguished the elite from the rest of the population (Cavieres, 2008).

\section{Falsification of European cheese in Chile}

In the 20th century, the ruling class in Chile encouraged the production of local cheese with falsified European AO and GI names instead of valuing, strengthening and protecting Chanco cheese and another national agro foods. Political leaders, technicians, communicators and merchants built a culture of imitation and counterfeit products originally made in Europe. This tendency extended to other products and became noticeable with the production of Chilean cognac and champagne from Aconcagua (Jeffs, 2014). In terms of cheese, Brie, Neufchatel and Cheddar were promoted, among other European agro foods made in Chile.
The position of the Chilean ruling class on the falsification of famous foreign agro foods was highlighted in the Boletín de la Sociedad Nacional de Agricultura (BSNA). As the official organ of the main business organization for Chilean farming, the BSNA became the primary intellectual reference for the country's rural production and conditioned the development of trends. From this influential position, the editors published various articles on cheese in which they explained the producers' position clearly. However, techniques for preparing the famous European cheeses, especially Brie and Neufchatel, were also given to promote their imitation in Chile (BSNA, 1869, 1870b). The BSNA encouraged Chilean producers to copy these products:

"For many years, the opinion prevailed that the quality of cheese depended on the type of animal, the influence of climate, and above all the nature of the grass. However, all types of cheese can be produced when the animals are given good food, whether in the pasture or in the stable, and when they are given the required care and kept in inconvenient hygienic conditions. Previously, it was believed that good Swiss cheese could only be made in Switzerland, but it is now also made quite easily in Bavaria, Alsace and Savoy. Switzerland has just lost its monopoly. Currently, Swiss cheese does not indicate that it was made in that country, but rather that it was manufactured according to the method observed in that country" (BSNA, 1870b).

The SNA's technicians tended to ignore the value of the geographic origin and identity of the previously mentioned products. SNA editors did not realize that they were dealing with monuments and products created and consolidated by the collective labor of the community in a determined territory. The editors of the BNSA confused AO with generic products and as a result cleared a path for the falsification of products. In parallel, the BSNA would minimize the value of Chanco cheese by stating that because of the aromatic grasses in Maule and Talca, a more exquisite and 
longer-lasting cheese than Chanco cheese could be manufactured:

"In Chanco, the cheese produced by ten quality cows during a good season is valued at two pounds per day. Therefore, one cow produces approximately 4 or 6 pesos-worth in three months, but they would produce 8 to 12 pesos-worth by adopting the system of the afore-mentioned gentlemen, whose cheese caught the attention of both producers and consumers" (BSNA, 1870b).

The tendency of the Chilean ruling class to promote the falsification of foreign agro foods was also reflected in the Senate. On July 20, 1928, the Senator for the Atacama and Coquimbo departments, Guillermo Azócar Álvarez, a prominent producer of milk and various milk by-products until 1941, made a relevant statement about the opportunities that the milk and cheese industries provided for Chilean economic and agrarian development.

"In the conference that took place at the National Society of Agriculture (SNA) yesterday, Mr. Correa Errázuriz indicated that the cheddar cheese industry must be developed in our country, and he assured that the entire stock of that type of cheese produced in Chile could easily be put in foreign markets" (Senado de Chile, 1928).

There was a very weak notion by many congressmen from that era about the relevance of the geographic origin of agricultural goods as a symbol of identity, quality and prestige. On December 5, 1928, Senators Gonzalo Urrejola and Joaquín Yrarrázabal and the commission's secretary discussed a draft legislation proposed by the Deputy Cardenio González, deputy from 1926 until 1930, to put (or not) the mark "made in Chile" on national products (Senado de Chile, 1928) with the following terms:

"The lack of legal dispositions about the origin of products has put our (Chilean) industries in a depressed position with respect to foreign ones.
Businessmen sell high-class Chilean products as foreign goods, and they do not declare those of inferior quality as national products, which could not compete on equal terms with foreign products. There is therefore a conscience that the product fabricated in our country does not have the qualities as those that come from abroad, and it will never have them" (Senado de Chile, 1929).

This law proposal was rejected by the Society of Industrial Development (SOFOFA) because of the abrupt drop in sales that the previously mentioned proposal could handle national goods as the Senator Joaquín Yrarrázabal Larraín, Senator of Provincial Group of Atacama and Coquimbo (1926-1934), did (Senado de Chile, 1929). Thus, the Chilean Senate made the practice of falsifying foreign products legitimate, encouraging the production of Cheddar cheese in Chile and confusing consumers. Cheddar cheese is an excellent example of a complex, generalized, and persistent culture of fraud, falsification and identity contamination that occurred in the Chilean elites from 1900 to 1930.

Chilean Brie cheese (Quillota Brie) was another falsified product manufactured during the last 30 years of the 19th century. It was a concrete attempt to copy a foreign product to obtain profits from the fame achieved through the efforts of the community of origin and was also an example of identity contamination.

Chilean Brie cheese became visible several times during the two aforementioned historical time periods. It was produced in several places, including the small town of Quillota, located between Valparaíso and Santiago on the western slope of the Coastal Mountain Range. In the 1880 s, Chilean Brie cheese was presented at fairs that were organized in that period to promote, compare, and award agro food products from various countries (Le Feuvre et al., 1886). One of those varieties was "Brie cheese of Quillota", distributed in Chile towards the end of the 19th century. This had been registered in a classified advertisement of Almacen Francés, published 
in El Coquimbo (March 27, 1899) (Figure 5). Brie cheese was presented at that time as an emblematic product. It was highlighted among the refined cheese category, along with Neufchatel cheese. However, time revealed the limits of this strategy. The Brie of Quillota cheese was not recognized by the markets but as an attempt by a few producers to gain an occasional commercial advantage.

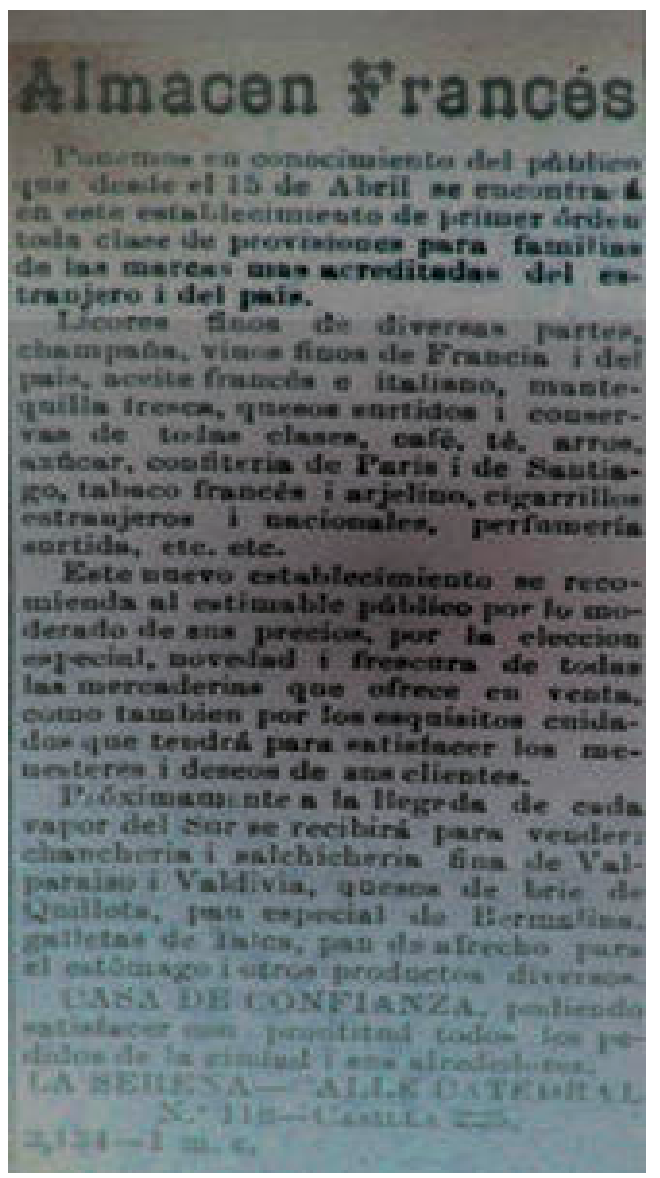

Figure 5. Almacén Francés' advertisement. Source: El Coquimbo, March 27, 1899.

The rising cycle (1860-1900) was characterized by the adaptation of Chanco cheese to the new advances of transport and communications. The expansion of railways and steam naviga- tion facilitated the arrival of Chanco cheese to all countries' food markets. Likewise, the diffusion of the press facilitated the promotion of Chanco cheese through newspaper ads across the country. Through these mechanisms, Chanco cheese succeeded in consolidating its leadership in the national market towards the end of the 19th century. The fame achieved by the Maule Sur community allowed Chanco cheese to be marketed at a higher price.

The rising cycle was followed by one of Chanco cheese decadence (1900-1930). In this stage, Chanco cheese lost the leadership that it had attained for 150 years in the Chilean market. The presence of Chanco cheese in print ads slowed down, and it was no longer among the national products whose market prices were followed daily in Valparaíso and Santiago. Chanco cheese went from being a central product in Chilean consumer habits to occupying a secondary position.

The decline of Chanco cheese occurred because of the incoherent action of the State, professionals and merchants. Chanco cheese was neither protected nor promoted as a product with a defined identity. Chanco cheese's productive zone was not delimited by the State. These groups devalued the identity of Chanco cheese as an AO and considered it generic, promoting its manufacture outside of its original zone.

Finally, several indicators made the declination of Chanco cheese noticeable: its presence in commercial advertisements became less frequent, reports on the evolution of mass consumption prices excluded it from the food basket, and the State's absolute omission on the issue. Unlike the AOs Pisco (Executive Order 181/1931), Pajarete (Executive Resolution 2,753/1979) and Vino Asoleado (Executive Resolution 2,753/1979), Chanco cheese was not protected nor recognized legally. 


\section{Acknowledgements}

This study was made possible by financial support from the Comisión Nacional de Investigación
Científica y Tecnológica (CONICYT, Chile) through the Regular FONDECYT Project 1130096 on "Appellations of Origin of Chilean Food and Agricultural Products".

\section{Resumen}

P. Lacoste, A. Castro, N. Soto, B. Rendón, F. Briones y D. Jiménez. 2015. El auge y caída del queso Chanco en Chile (1860-1930). Cien. Inv. Agr. 42(1): 85-96. Este trabajo examina la evolución del queso Chanco dentro de dos ciclos diferenciados, que corresponden a los periodos 1860-1900 y 1900-1930. El primero, caracterizado por una alta presencia de aquel queso en la prensa escrita del periodo y un alto nivel de consumo del mismo dentro de la sociedad chilena, mientras que el segundo ciclo tuvo lugar en medio de una profunda contaminación identitaria con los productos provenientes de Europa. A modo de hipótesis, postulamos que, a diferencia de lo ocurrido con productos tales como el Pisco, que acabaron siendo delimitados y protegidos mediante las Denominaciones de Origen (DO), el queso Chanco fue víctima de una dilución de su identidad y valor cultural debido a las acciones incoherentes del Estado, los productores y los comerciantes en cuanto a su valoración, protección y delimitación.

Palabras clave: Agroalimentos, Chile, contaminación identitaria, denominaciones de origen, queso Chanco.

\section{References}

BSNA-Sociedad Nacional de Agricultura. 1869. Fabricación de quesos (parte I). BSNA. Vol. VI 25 de diciembre. Santiago de Chile. p. 113116.

BSNA-Sociedad Nacional de Agricultura. 1870a. Del 16 de octubre de 1869 al 16 de octubre de 1870. Vol. I. Santiago de Chile. p. 336-337.

BSNA-Sociedad Nacional de Agricultura. 1870b. Fabricación de quesos (parte II). BSNA. Vol. VII 20 de enero. Santiago de Chile. p. 132-135.

Cavieres, E. 2008. Historia del comercio en Chile. Siglo XVIII al XX. Del mercado colonial a los centros comerciales actuales. Cámara de Comercio de Santiago. Santiago de Chile. 176 pp.

Coello, C. 2008. Las Bases Históricas y Administrativas del Derecho Vitivinícola Español. El Sistema Jurídico de las Denominaciones de Origen. Junta de Andalucía. Instituto Andaluz de Administración Pública. Conserjería de Justicia y Administración Pública. Sevilla. España. $1460 \mathrm{pp}$.
Delfosse, C. 1997. Noms de pays et produits du terroir: enjeux des dénominations géographiques. Espace géographique 26:222-230.

Dussaillant, J. 1993. Breve historia de los avisos publicitarios en los principales periódicos chilenos 1850-1920. Tesis de Licenciatura en Historia. Pontificia Universidad Católica de Chile. $216 \mathrm{pp}$.

Jeffs, J.G. 2014. Coñac, Pisco, Jerez y Oporto: batallas comerciales a través de la prensa chilena (1870-1885). RIVAR 1:75-85.

Le Feuvre, R., L. Barros, D. Ovalle and M. Rojas. 1886. Exposición Departamental de Los Andes. Informe de la Comisión nombrada para estudiar dicha exposición. BSNA. Vol. XVIII. 5 de noviembre. $41 \mathrm{pp}$.

Lacoste, P., D. Jiménez, and N. Soto. 2014. Genesis and identity of Chanco cheese (Chile 17501860). A contribution to studies on Appellations of Origin in Latin America. Ciencia e Investigación Agraria 41:317-325.

Molina, J. I. 1987. Ensayo de la historia natural de Chile. Ediciones Maule. Santiago de Chile. 383 pp. 
Pereira, E. 1977. Apuntes para la historia de la cocina chilena. Editorial Universitaria. Santiago de Chile. 158 pp.

Perrier-Cornet, P., and S. Bertil. 2000. Firmes, coordinations et territorialité Une lecture économique de la diversité des filières d'appellation d'origine. Économie rurale 258:79-89.
Senado de Chile. 1928. Boletín de las Sesiones Ordinarias de 1928. Imprenta La Nación. 1180 pp.

Senado de Chile. 1929. Boletín de las Sesiones Ordinarias de 1928-1929. Imprenta La Nación. Tomos I y II. 2150 pp. 